\title{
Mandibular reconstruction: a review
}

\author{
Dr. Mir Nowazesh Ali ${ }^{1 *}$, Dr. Rezwana Binte Anwar², Dr. Ruman Banik ${ }^{3}$, Dr. Sajid Hasan4, \\ Dr. Md. Raihan UI Arefin ${ }^{5}$, Dr. Md. Wares Uddin 6
}

AFFILIATION:

1. DR. MIR NOWAZESH ALI, BDS, MS (Oral \& Maxillofacial Surgery), PhD Assistant Professor, Oral \& Maxillofacial Surgery Department Bangabandhu Sheikh Mujib Medical University

2. DR. REZWANA BINTE ANWAR,BDS, PhD (Prosthodontics) Resident, Department of Prosthodontics Bangabandhu Sheikh Mujib Medical University

3. DR. RUMAN BANIK ,BDS, MS (Oral \& Maxillofacial Surgery) Medical Officer, Oral \& Maxillofacial Surgery Department Bangabandhu Sheikh Mujib Medical University

4. DR. SAID HASAN, BDS, FCPS (Oral \& Maxillofacial Surgery) Assistant Professor, Ibrahim Medical College Junior Consultant, Department of Dental Surgery, BIRDEM General Hospital

5. DR. MD. RAIHAN-UL AREFIN, BDS, MCPS, FCPS, MS (Oral \& Maxillofacial Surgery) Dental Surgeon, Upazilla Health Complex, Chatkhil, Noakhali

6. DR. MD. WARES UDDIN BDS, MS (Oral \& Maxillofacial Surgery) Associate Professor, Oral \& Maxillofacial Surgery Department Bangabandhu Sheikh Mujib Medical University

\section{Article info.}

Received: $20^{\text {th }}$ August, 2019

Accepted: $15^{\text {th }}$ September, 2019

Volume: 9, Issue-2 October, 2019

DOI: https://doi.org/10.3329/updcj.v9i2.43742

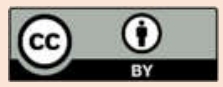

(c) Authors retain copyright and grant the journal right of first publication with the work simultaneously licensed under Creative Commons Attribution License CC - BY 4.0 that allows others to share the work with an acknowledgment of the work's authorship and initial publication in this journal.

https://creativecommons.org/licenses/by/4.0/

Publisher: Update Dental College, Dhaka, Bangladesh

Web: www.updatedentalcollege.edu.bd

E-mail: updcj@hotmail.com

* Corresponding Author DR. MIR NOWAZESH ALI

BDS, MS (Oral \& Maxillofacial Surgery), PhD

Assistant Professor, Oral \& Maxillofacial Surgery Department Bangabandhu Sheikh Mujib Medical University e-mail: thebestdentist@yahoo.com Cell: +8801730000285

\begin{abstract}
Mandibular defects may occur from maxillofacial injury, inflammatory disease, benign or malignant tumour resections and osteoradionecrosis. Mastication, speech and facial disfigurement are often severely compromised without reconstruction leading to poor quality of life. The goal of mandibular reconstruction is to restore facial form and function, repair of mandibular continuity and soft tissue reanimation. Implant insertion should be feasible to allow occlusal rehabilitation and if possible the inferior alveolar nerve function should be restored. Mandibular reconstruction principles and techniques have evolved dramatically over the years. Refinements in techniques continue to improve patient quality of life. This paper reviews short history, current techniques and few promising future endevours related to mandibular reconstruction.
\end{abstract}

\section{KEYWORDS:}

Mandibular reconstruction, Bone plates, Bone grafts, Free flaps, Dental prosthetics, Implants, 3D additive manufacturing, Tissue engineering.

\section{INTRODUCTION:}

Mandibular defects can result from trauma, infection, benign or malignant tumor resection or osteoradionecrosis. Surgeons worldwide have been trying to reconstruct mandibles for more than a century ${ }^{1}$. Significant progress was made over particularly the last 40 years, but the ideal solution - implying an anatomical reconstruction with sufficient height to accommodate dental implants and adequate soft tissue coverage to allow for normal function has not yet been achieved. Another challenge is to restore the function of the inferior alveolar nerve. None of the presently available techniques can meet all these needs, and so the search for a better means of reconstruction should continue.

It is the aim of the present review to discuss the short history, existing techniques and upcoming modalities of mandibular reconstruction.

\section{HISTORY}

The history of mandibular reconstruction is surprisingly old and still evolving. The first case was reported in 1892 by Bardenheuer who used a pedicle graft of the mandible itself to restore its continuity (Figure 1$)^{2}$. Martin performed the immediate restoration of a resected mandible with a prosthetic appliance ${ }^{3}$. Metal band was used by Partsch to restore the mandibular continuity ${ }^{4}$, Berndt applied celluloid material, White ${ }^{5}$ recommended silver wire, Scudder et al favoured hard rubber ${ }^{6}$ and Konig employed ivory. Metals were also used; Stainless steel ${ }^{7}$, Vitallium, and Titanium. The idea of delayed reconstruction evolved sometime during the World 
War I using grafting to treat mandibular defects ${ }^{8}$. The introduction of internal fixation using plate and screws post World War II with the advantage of using antibiotics gave surgeons high success rate over the previous procedures ${ }^{9}$. The next thing adopted were free, nonvascularized, bone grafts ${ }^{10}$, harvested in distant locations and held in place, at the receptor site, by metallic reconstruction plates, usually titanium. Several bones, such as tibia, iliac crest, or ribs, were often used as donor sites ${ }^{9}$. Use of threaded Kirschner (K) wire in 47 patients were reported by Castermans et al. ${ }^{11}$ in 1977. Bowerman used titanium plate to reconstruct the mandible in 17 patients $^{12}$. Leuke and Rappaport, Schwartz and Albert and associates addressed the use of Dacron urethane mesh for holding the cancellous chips ${ }^{13}$. Wersal et al. ${ }^{14}$ addressed splitrib grafts for the mandibular reconstruction. Bradley ${ }^{15}$ in 1978 and 1982 reported a two-stage procedure for reimplantation of 'autogenous freeze treated mandibular bone'. It was further evident by Dong et al. ${ }^{16}$ through a large series of mandibular reconstruction using 'autogenous freeze treated mandibular bone' for tumours of the mandible and floor of the mouth. Taylor, as well as Sanders and Mayou described the deep circumflex iliac artery and vein (DCIA/V) based free transfer of iliac bone and the overlying skin as a reliable and easily utilizable reconstruction option ${ }^{17}$. For the first time, Swartz et al. ${ }^{18}$ introduced the scapular osteocutaneous free flap (SOFF) in 1986 for use in head and neck reconstruction. Another milestone achieved in 1989, Hidalgo ${ }^{19}$ introduced the transfer of fibula bone to reconstruct a segmental defect of the mandible. Recently, in 2010, partial soleus muscle combined with fibula osteoseptocutaneous flap for dead space obliteration aws reported by Kuo et al. ${ }^{20}$.

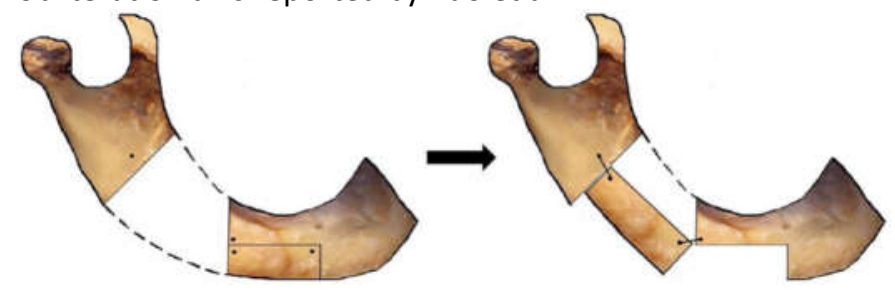

Figure 1. Schematic image of the pedicle bone graft performed by Bardenheuer.

\section{GOALS OF RECONSTRUCTION}

Mandible, the U-shaped bone which forms bony foundation of the lower face and extremely important for facial aesthetics ${ }^{21}$. It also serves as the attachment for tongue and muscles of the floor of the mouth. Functions of mandible include mastication, deglutition, airway patency and speech which need complex units of tissue. In addition, to bear the dentition is unique to mandible.

Thus, any attempt to reconstruct a mandible would ideally need to reconstruct the height and shape of the missing part anatomically, to provide a platform for dental rehabilitation post reconstruction, to manage the forces that act on the mandible in normal functioning, to withstand similar fracture threshold to the intact mandible, to allow early or immediate masticatory function, restoration of the supporting muscle and soft tissue envelope, to allow normal sensation to the lips and tongue, to be simple, flexible, and cost effective and to be able to sustain repeated loading ${ }^{22}$. The gold standard of replacing like-with-like frequently needs the use of composite tissues as well. Taking all variables into consideration the principle of reconstruction for intra-oral hard tissue defects should establish continuity, restore soft tissue loss, establish alveolar height, width and form, improve facial contours and restore functions - dental rehabilitation, mastication, deglutition, speech and oral competence ${ }^{23}$.

\section{CURRENT RECONSTRUCTIVE OPTIONS}

Surgical management of several conditions occurring in mandible require the resection of the pathology along with good margin. After resection, the defect might be limited to hard tissue only or may affect both hard and soft tissue which mandates reconstruction not only to replace the missing structural component, but also to restore the associated function and aesthetics ${ }^{23}$. This restoration of form and the function becomes more and more difficult as the tissues resected become larger and complex in nature. The following reconstructive ladder is a list of options starting from the simplest to the more complex methods currently available:

1. Healing by secondary intention and/or primary closure

2. Skin graft

3. Skin graft substitutes

4. Reconstructive plate

5. Autogenous bone grafts

- vascularized and

- non-vascularized

6. Bone graft substitutes

7. Regional flaps and distant flaps

eg. Pectoralis major myocutaneous flap, Latissimus dorsi flap etc.

8. Vascularized free flaps

eg. Fibula flap, Scapula flap, Radial bone flap, Metatarsal bone flap etc.

9. Recent advances

eg. Transport disc distraction osteogenesis, Modular endoprosthesis, 3D printed custom made prosthesis, tissueengineering, stem cell technology etc.

RECENT ADVANCES AND POSSIBLE FUTURE DEVELOPMENTS Recently, new techniques for mandibular reconstruction have been tested, with a common aim of eliminating the need for harvesting bone from a donor site ensuring less surgical morbidities ${ }^{1}$. These include transport disc distraction osteogenesis (TDDO), modular endoprosthesis, tissue engineering and stem cells. Application of 3D printing also hold bright future in the reconstruction of mandibular defect along with innovative materials coming soon to be capable of printing biocompatible prosthesis.

\section{TDDO}

The first clinical cases of mandibular lengthening by distraction osteogenesis were reported by McCarthy in $1992^{24}$. Since then, 
this technique continues to evolve. Recently, a modification known as TDDO (Figure 2) is used to reconstruct mandible. A segment of bone is cut adjacent to the defect and moved gradually across the defect by a distraction device. New bone fills in between the two bone segments. The piece

of bone being moved or transported is called as the transport disc ${ }^{25}$. In 1995, Costantin, et al. ${ }^{26}$ successfully applied transport distraction to restore the continuity of a mandibular defect formed as a result of cancer ablation. The main drawback of distraction remains the time required to regenerate the new bone. Difficulties with the direction control and device dislodgement also harm the reconstruction sometimes. Better understanding with time and multi directional vector control will allow for greater use of this procedure.

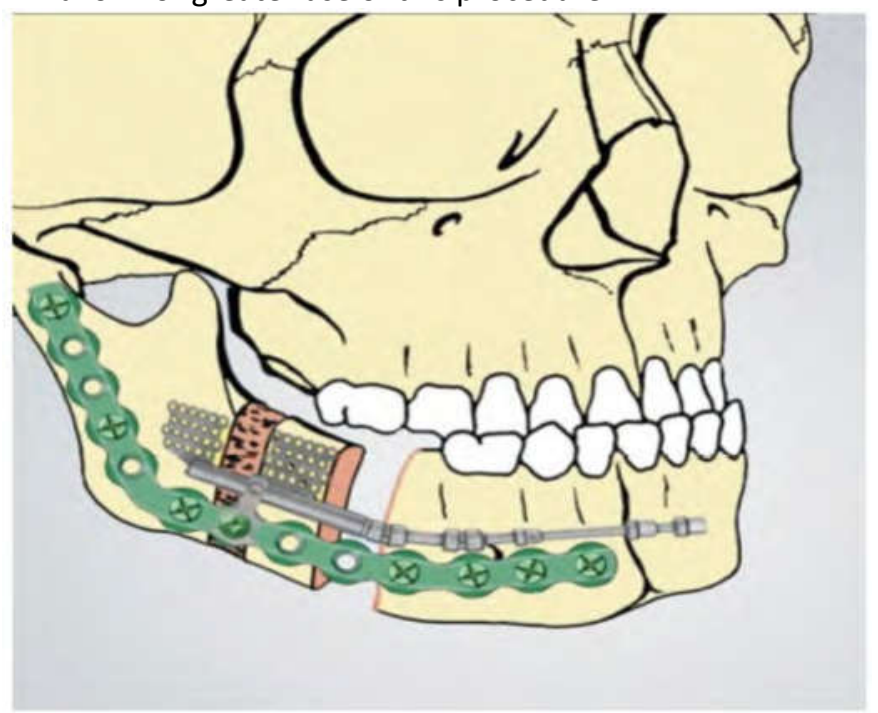

Figure 2: "Segmental Mandibular Regeneration by Distraction Osteogenesis: An Experimental Study" - Costantino, P. D. Et al.

\section{MODULAR ENDOPROSTHESIS}

Active communication between different specialties in the medical field can always bring wonderful results. 'Modular endoprosthesis'- A concept which has been applied in the orthopaedic community for almost 10 years was recently introduced by Tideman and $\mathrm{Lee}^{27}$ for reconstruction of monkey's mandible. An endoprosthesis is a metallic device that replaces diseased bone in long bones and is fixed internally with bone cement within the medullary space of the remaining healthy bone. No screw fixation is required. The variable length of the bone gap can be bridged by using modules that allow for accurate three-dimensional reconstructions. The modules are connected by a locking system.

In principle, the mandible is also a suitable candidate for such an endoprosthesis because of the existing medullary space. Dental rehabilitation could be achieved by screwing implants into existing holes of the endoprosthesis. Immediate accurate three-dimensional replacement of the lost part of the mandible would be achievable, and after setting of the bone cement immediate function would be possible because no screws are involved. Whether this system will also work in patients with compromised soft tissues remains to be seen, but the principle is worthy of further research.

\section{TISSUE-ENGINEERING}

To date, there is only one published case of successful reconstruction of the mandible in human, using the principle of tissue engineering ${ }^{28,29}$. As reported by Warnke et al., it concerned a patient who underwent a secondary reconstruction after tumour resection. The engineered graft was allowed to heal in the trapezius muscle and subsequently transplanted to the recipient side, using microvascular anastomosis. This clinical application was largely based on research carried out on minipigs by Terheyden et al. ${ }^{30,31}$. Bone morphogenetic protein-2 (BMP-2) and BMP-7 were extensively used in tissue engineering. In principle, engineering a graft at the site of the defect would be more preferable. Moreover, it would require prolonged period of mandible immobilization with adequate soft-tissue coverage for healing. Although there is definitely a future for engineered grafts their routine clinical application is still a long way off. Apart from the technical problems there oncologic potential is a big question which requires further clarification. Another big factor is the high costs involved in using currently available bone morphogenetic proteins. However, autogenous growth factors, like those present in platelets, are mainly mitogenetic and are not known to be oncogenetic.

\section{STEM CELLS IN MANDIBULAR RECONSTRUCTION}

The regeneration of human tissues using stem cells from the patient, seeded in specially designed resorbable scaffolds and placed into a bioreactor which could simulate the natural conditions $^{32,33}$, is an extremely exciting field that will certainly change not only the way in which mandible reconstruction takes place but also how medicine as a whole is practiced. Adipose stem cells have primarily been used in addition to tricalcium phosphate granules and recombinant human BMP. Sandor et al..$^{34}$ documented a successful reconstruction of a 10$\mathrm{cm}$ full defect of the mandible using adipose stem cells, tricalcium phosphate granules and recombinant human BMP without ectopic bone maturation. After 10-month maturation, dental implants were installed and bone formation was confirmed.

\section{D ADDITIVE MANUFACTURING AND NEW PROSTHETIC DEVICES}

The application of computer aided design and computer aided manufacturing (CAD/CAM) using the high end 3D printers with bio compatible printing materials are capable of mimicking the complex anatomy of mandible with the perfect size, shape and contour. The customization of the device should go even further by reproducing the original geometry and weight, and can change the paradigm from simple titanium plates to customized prosthesis. Finally, the new prosthetic device could be prepared to include tissue regeneration strategies (Figure 3) as used by Zhou et al ${ }^{35}$. 


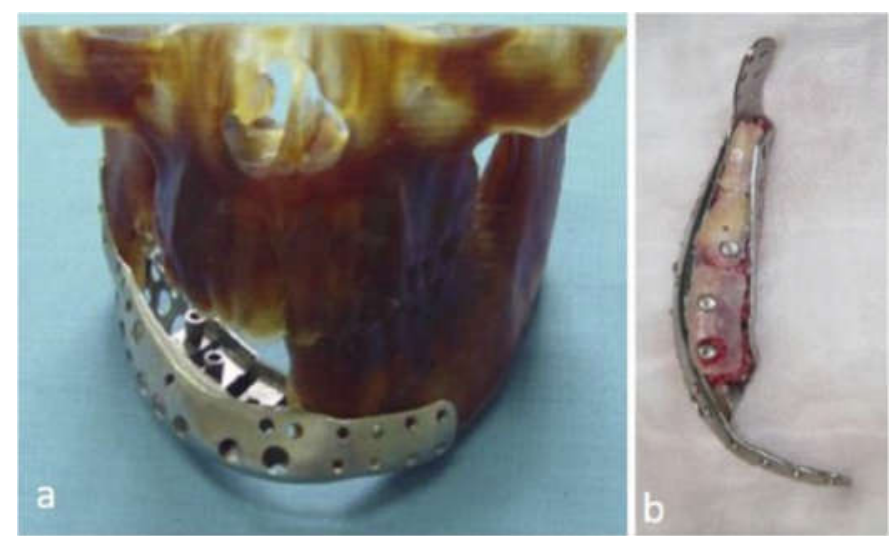

Figure 3: (a) Prosthetic device placed in a mandible model and (b) the prosthetic device including tissue regeneration strategies. Source: adapted from Zhou et al. ${ }^{35}$

In the recent years, partial and complete face transplants have been conducted since 2005, the first of which was performed in France $^{36}$. Complete mandibular reconstruction has been documented in literature by Devauchelle et al. and the company Xilloc Medical BV manufactured and used a customized 3D printed lower jaw for complete mandibular restoration (Figure 4).

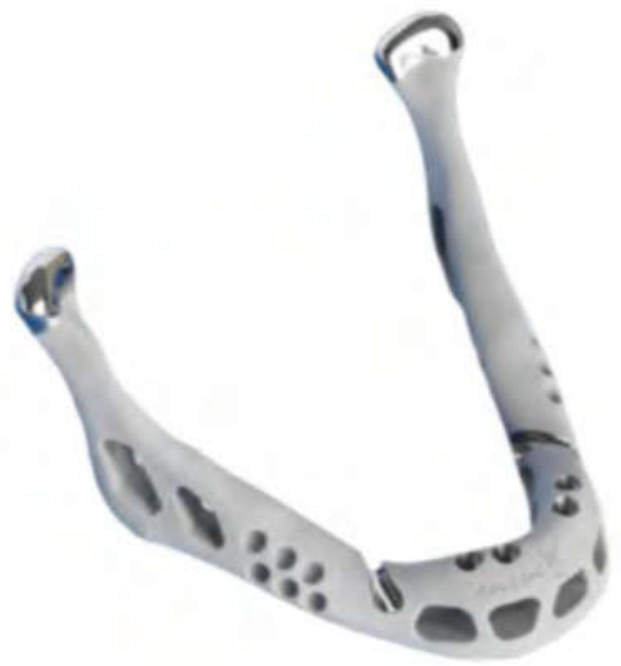

Figure 4: First Human Face Allograft using 3D printed mandible. Source: adapted from Devauchelle et al. ${ }^{36}$

\section{CONCLUSION}

This review confirms that there is no ideal solution for mandibular reconstruction. Each of the methods discussed has its shortcomings and limitations. Mandibular reconstruction cannot be completed perfectly without maintaining ideal soft tissue conditions that are frequently compromised. Another important issue is the sensory problems often noted with cancer patients who received ablative surgery. Quality-of-life studies have clearly pointed out the importance of above mentioned fundamental functions reported by the suffering patients ${ }^{37-40}$. Unfortunately, a reconstructed mandible with implants and occlusal rehabilitation on implants is not enough to restore these functions completely. Newer methods of mandibular reconstruction have been explored with varying degrees of success, but it remains to be seen whether these methods can overcome all the limitations.

53 | P a g e

\section{REFERENCES:}

1. Goh BT, Lee S, Tideman H, Stoelinga PJ. Mandibular reconstruction in adults: a review. International journal of oral and maxillofacial surgery. $2008 \mathrm{Jul}$ 1;37(7):597-605. https://doi.org/10.1016/j.ijom.2008.03.002

PMid:18450424

2. IVY RH. Bone grafting for restoration of defects of the mandible. Plastic and Reconstructive Surgery. 1951 Apr 1;7(4):333-41.

https://doi.org/10.1097/00006534-195107040-00009

3. Testelin S. History of microsurgical reconstruction of the mandible. Ann Chir Plast Esthet. 1992 Jun;37(3):241-245

4. Defries HO. Reconstruction of the mandible: use of combined homologous mandible and autologous bone. Otolaryngology--Head and Neck Surgery. 1981 Jul;89(4):694-7. https://doi.org/10.1177/019459988108900433

PMid:6793984

5. White S. The employment of silver wire to bridge the gap after resection of a portion of the lower jaw. British medical journal. 1909 Nov 27;2(2552):1525. https://doi.org/10.1136/bmj.2.2552.1525

PMid:20764767 PMCid:PMC2321319

6. Lowlicht RA, Delacure MD, Sasaki CT. Allogeneic (homograft) reconstruction of the mandible. The Laryngoscope. 1990 Aug;100(8):837-43. https://doi.org/10.1288/00005537-199008000-00008 PMid:2381260

7. Attie JN, Catania A, Ripstein CB. A stainless steel mesh prosthesis for immediate replacement of the hemimandible. Surgery. 1953 May;33(5):71220.

8. Donkor P, Bankas DO, Boakye G, Ansah S, Acheampong AO. The use of free autogenous rib grafts in maxillofacial reconstruction. Ghana medical journal. 2006;40(3). https://doi.org/10.4314/gmj.v40i3.55266

9. Blocker Jr TG, STOUT RA. Mandibular reconstruction, World War II. Plastic and Reconstructive Surgery. 1949 Mar 1;4(2):153-6. https://doi.org/10.1097/00006534-194903000-00004

10. Pogrel MA, Podlesh S, Anthony JP, Alexander J. A comparison of vascularized and nonvascularized bone grafts for reconstruction of mandibular continuity defects. Journal of oral and maxillofacial surgery. 1997 Nov 1;55(11):1200-6. https://doi.org/10.1016/S0278-2391(97)90165-8

11. Castermans A, Vanwijck R. Primary reconstruction of the mandible after resection for oral cancer. Acta chirurgica Belgica. 1977;76(2):203-8.

12. Bowerman JE. A review of reconstruction of the mandible. Proc R Soc Med. 1974 Jul;67(7):610-14.

https://doi.org/10.1177/003591577406700717

13. Albert TW, Smith JD, Everts EC, Cook TA. Dacron mesh tray and cancellous bone in reconstruction of mandibular defects. Archives of OtolaryngologyHead \& Neck Surgery. 1986 Jan 1;112(1):53-9.

https://doi.org/10.1001/archotol.1986.03780010055010 PMid:2934044

14. Wersäll J, Bergstedt H, Körlof B, Lind MG. Split-rib graft for reconstruction of the mandible. Otolaryngology-Head and Neck Surgery. 1984 Jun;92(3):2706. https://doi.org/10.1177/019459988409200305

15. Bradley PF. A two-stage procedure for reimplantation of autogenous freeze-treated mandibular bone. Journal of Oral and Maxillofacial Surgery. 1982 May 1;40(5):278-84.

https://doi.org/10.1016/0278-2391(82)90218-X

16. Dong YJ, Zhang GZ, Wang SP, Li Z. The use of immediate frozen autogenous mandible, for benign tumour mandibular reconstruction. British Journal of Oral and Maxillofacial Surgery. 1996 Feb 1;34(1):58-61.

https://doi.org/10.1016/S0266-4356(96)90137-0

17. Taylor GI, Townsend P, Corlett R. Superiority of the deep circumflex iliac vessels as the supply for free groin flaps. Clinical work. Plastic and Reconstructive Surgery. 1979 Dec;64(6):745-59.

https://doi.org/10.1097/00006534-197912000-00001 PMid:390575

18. Swartz WM, Banis JC, Newton ED, Ramasastry SS, Jones NF, Acland R. The osteocutaneous scapular flap for mandibular and maxillary reconstruction. Plastic and Reconstructive Surgery. 1986 Apr;77(4):530-45.

https://doi.org/10.1097/00006534-198604000-00003 PMid:3952209

19. Hidalgo DA. Fibula free flap: a new method of mandible reconstruction Plastic and reconstructive surgery. 1989 Jul;84(1):71-9.

https://doi.org/10.1097/00006534-198907000-00014

20. Kuo YR, Shih HS, Chen CC, Boca R, Hsu YC, Su CY, Jeng SF, Wei FC. Free fibula osteocutaneous flap with soleus muscle as a chimeric flap for reconstructing mandibular segmental defect after oral cancer ablation. Annals of Plastic Surgery. 2010 Jun 1;64(6):738-42.

Website: https://www.banglajol.info/index.php/UpDCJ 


\section{https://doi.org/10.1097/SAP.0b013e3181a72f62}

PMid:20407367

21. McCarthy CM, Cordeiro PG. Microvascular reconstruction of oncologic defects of the midface. Plastic and reconstructive surgery. 2010 Dec 1;126(6):1947-59. https://doi.org/10.1097/PRS.0b013e3181f446f1

PMid:20697315

22. Wong RC, Tideman H, Kin L, Merkx MA. Biomechanics of mandibular reconstruction: a review. International journal of oral and maxillofacial surgery. 2010 Apr 1;39(4):313-9.

https://doi.org/10.1016/i.ijom.2009.11.003 PMid:19944568

23. Pai D, Wodeyar A, Raja P, Nishad M, Martis E, Kumar K. Evolution of Mandibular Defects Reconstruction Procedures: From Older Principles to Newer Techniques and Technology. Acta Scientific Dental Sciences. 2019 May;3(5): 08-18. https://doi.org/10.31080/ASDS.2019.03.0635

24. McCarthy JG, Schreiber J, Karp N, Thorne CH, Grayson BH. Lengthening the human mandible by gradual distraction.

25. Sacco AG, Chepeha DB. Current status of transport-disc-distraction osteogenesis for mandibular reconstruction. The lancet oncology. $2007 \mathrm{Apr}$ 1;8(4):323-30. https://doi.org/10.1016/S1470-2045(07)70102-X

26. Costantino PD, Johnson CS, Friedman CD, Sisson Sr GA. Bone regeneration within a human segmental mandible defect: a preliminary report. American journal of otolaryngology. $1995 \operatorname{Jan}$ 1;16(1):56-65.

https://doi.org/10.1016/0196-0709(95)90011-X

27. Tideman $\mathrm{H}$, Lee $\mathrm{S}$. The TL endoprosthesis for mandibular reconstruction- $A$ metallic yet biological approach. Asian J Oral Maxfac Surg. 2006;18(5).

28. Warnke PH, Springer IN, Wiltfang J, Acil Y, Eufinger H, Wehmöller M, Russo PA, Bolte H, Sherry E, Behrens E, Terheyden H. Growth and transplantation of a custom vascularised bone graft in a man. The Lancet. 2004 Aug 28;364(9436):766-70. https://doi.org/10.1016/S0140-6736(04)16935-3

29. Warnke PH, Wiltfang J, Springer I, Acil Y, Bolte H, Kosmahl M, Russo PA, Sherry E, Lützen $\mathrm{U}$, Wolfart S, Terheyden $\mathrm{H}$. Man as living bioreactor: fate of an exogenously prepared customized tissue-engineered mandible. Biomaterials. 2006 Jun 1;27(17):3163-7.

https://doi.org/10.1016/j.biomaterials.2006.01.050 PMid:16504287

30. Terheyden H, Knak C, Jepsen S, Palmie S, Rueger DR. Mandibular reconstruction with a prefabricated vascularized bone graft using recombinant human osteogenic protein-1: an experimental study in miniature pigs. Part I: Prefabrication. International journal of oral and maxillofacial surgery. $2001 \mathrm{Oct}$ 1;30(5):373-9. https://doi.org/10.1054/ijom.2001.0032 PMid:11720037

31. Terheyden $H$, Menzel C, Wang $H$, Springer IN, Rueger DR, Acil Y. Prefabrication of vascularized bone grafts using recombinant human osteogenic protein-1-part 3: dosage of rhOP-1, the use of external and internal scaffolds. International journal of oral and maxillofacial surgery. $2004 \mathrm{Mar}$ 1;33(2):164-72. https://doi.org/10.1054/ijom.2003.0500 PMid:15050073

32. Hutmacher D, Woodfield T, Dalton P. Scaffold design and fabrication. In: Blitterswijk CV (ed.) Tissue engineering. 1st ed. London: Elsevier, 2008, 40448. https://doi.org/10.1016/B978-0-12-370869-4.00014-8

33. Jukes J, Both S, Post J. Stem cells. In: Blitterswijk CV(ed.) Tissue engineering. 1st ed. London: Elsevier, 2008, 2-24.

https://doi.org/10.1016/B978-0-12-370869-4.00001-X

34. Sándor GK, Tuovinen VJ, Wolff J, Patrikoski M, Jokinen J, Nieminen E, Mannerström B, Lappalainen OP, Seppänen R, Miettinen S. Adipose stem cell tissue-engineered construct used to treat large anterior mandibular defect: a case report and review of the clinical application of good manufacturing practice-level adipose stem cells for bone regeneration. Journal of Oral and Maxillofacial Surgery. 2013 May 1;71(5):938-50.

https://doi.org/10.1016/j.joms.2012.11.014 PMid:23375899

35. Zhou LB, Shang HT, He LS, Bo B, Liu GC, Liu YP, Zhao JL. Accurate reconstruction of discontinuous mandible using a reverse engineering/computer-aided design/rapid prototyping technique: a preliminary clinical study. Journal of Oral and Maxillofacial Surgery. $2010 \mathrm{Sep}$ 1;68(9):2115-21. https://doi.org/10.1016/i.joms.2009.09.033

PMid:20542365

36. Devauchelle B, Badet L, Lengelé B, Morelon E, Testelin S, Michallet M, D'Hauthuille C, Dubernard JM. First human face allograft: early report. The Lancet. 2006 Jul 15;368(9531):203-9.

https://doi.org/10.1016/S0140-6736(06)68935-6
37. Rogers SN, Lowe D, Fisher SE, Brown JS, Vaughan ED. Health-related quality of life and clinical function after primary surgery for oral cancer. British Journal of Oral and Maxillofacial Surgery. 2002 Feb 1;40(1):11-8. https://doi.org/10.1054/bjom.2001.0706 PMid:11883963

38. Schliephake H, Jamil MU. Impact of intraoral soft-tissue reconstruction on the development of quality of life after ablative surgery in patients with oral cancer. Plastic and reconstructive surgery. 2002 Feb;109(2):421-30. https://doi.org/10.1097/00006534-200202000-00001

PMid:11818814

39. Schliephake H, Neukam FW, Schmelzeisen R, Varoga B, Schneller H. Longterm quality of life after ablative intraoral tumour surgery. Journal of CranioMaxillofacial Surgery. 1995 Aug 1;23(4):243-9.

https://doi.org/10.1016/S1010-5182(05)80215-X

40. Schliephake H, Rüffert K, Schneller T. Prospective study of the quality of life of cancer patients after intraoral tumor surgery. Journal of oral and maxillofacial surgery. 1996 Jun 1;54(6):664-9.

https://doi.org/10.1016/S0278-2391(96)90676-X 